\title{
COMMUNICATION OF PROFESSIONAL CAREGIVERS IN ESTABLISHING INTERPROFESSIONAL COLLABORATION AT MEURAXA HOSPITAL, BANDA ACEH
}

\author{
Komunikasi Profesional Pemberi Asuhan dalam Membangun Interprofessional \\ Collaboration di RSUD Meuraxa Banda Aceh
}

\author{
Sri Wahyuni ${ }^{1}$, Nova Dian Lestari ${ }^{2},{ }^{*}$ Dedy Syahrizal ${ }^{3}$ \\ ${ }^{1}$ Faculty of Medicine, Universitas Syiah Kuala, Banda Aceh, Indonesia \\ ${ }^{2}$ Department of Neurology, Faculty of Medicine, Universitas Syiah Kuala, Banda Aceh, Indonesia \\ ${ }^{3}$ Department of Biochemistry, Faculty of Medicine, Universitas Syiah Kuala, Banda Aceh, Indonesia \\ Correspondence* \\ Address: Jl. Tgk Tanoh Abee Kopelma Darussalam, Banda Aceh, Indonesia | e-mail: dedysyahrizal@unsyiah.ac.id
}

\begin{abstract}
Background: Interprofessional collaboration for patient care is integrated cooperation between health workers in ensuring optimally consecutive patient care. Interprofessional decisions should be made in two ways between professional caregivers. Aims: This study aimed to analyze communication between professional caregivers in establishing interprofessional collaboration at Meuraxa District General Hospital in Banda Aceh.

Method: This study was qualitative research and used a phenomenological approach. In-depth interviews and FGD were conducted with professional caregivers consisting of doctors in charge, nurses, pharmacists, and dietitians. All of the in-depth interviews and FGD were recorded and transcribed. Data obtained were analyzed thematically.

Results: Communication between professional caregivers in establishing interprofessional collaboration at the hospital had not been well-performed. Overall, they had not optimally utilized integrated patient progress records as they focused on taking care of their patients individually. They also lacked literacy about the information in the records. Inadequate time in serving patients and the insufficient number of human resources were presumed to hamper interprofessional communication.

Conclusion: Promoting interprofessional collaboration and effective communication regularly is required by the hospital management. They also need to evaluate the sufficiency of human resources, especially pharmacist positions. Besides, they can formulate supervision and evaluation systems of interprofessional communication between professional caregivers.
\end{abstract}

Keywords : collaboration, communication, integrated patient progress record, interprofessional, professional caregivers

\begin{abstract}
Abstrak
Latar Belakang: Kolaborasi interprofesional merupakan bentuk kerjasama antar tenaga kesehatan untuk memastikan keputusan asuhan pasien berjalan optimal dan berkesinambungan. Pengambilan keputusan bersama merupakan komunikasi dua arah antar Profesional Pemberi Asuhan (PPA).

Tujuan: Penelitian ini bertujuan untuk menganalisis praktik komunikasi PPA dalam implementasi Kolaborasi interprofesional di RSUD Meuraxa Kota Banda Aceh.

Metode: Penelitian ini merupakan penelitian kualitatif dengan pendekatan fenomenologi. Wawancara mendalam dan FGD dilaksanakan bersama PPA yang meliputi Dokter (DPJP), perawat, apoteker, dan ahli gizi. Proses interview dan FGD direkam dan ditranskripsi. Data dianalisis secara tematik.

Hasil: Praktik komunikasi PPA dalam pelaksanaan kolaborasi interprofesional di RSUD Meuraxa belum terlaksana secara optimal. PPA belum memanfaatkan Catatan Perkembangan Pasien Terintegrasi (CPPT) dengan baik karena lebih fokus melakukan asuhan secara mandiri. Budaya membaca informasi PPA lain dalam CPPT masih kurang. Keterbatasan waktu saat melakukan pelayanan dan kurangnya SDM disinyalir sebagai hambatan dalam melaksanakan komunikasi secara interprofesional.

Kesimpulan: Sosialisasi pelaksanaan kolaborasi interprofesional dan komunikasi efektif secara berkala perlu dilakukan. Pihak manajemen rumah sakit harus melakukan telaah staf untuk menyediakan SDM yang cukup, terutama profesi apoteker. Selain itu, mereka juga harus membuat pola supervisi serta evaluasi terhadap pelaksanaan komunikasi antar PPA
\end{abstract}

Kata kunci: catatan perkembangan pasien terintegrasi, kolaborasi antar profesi, komunikasi, profesional pemberi asuhan 


\section{Introduction}

Interprofessional collaboration for patient care is teamwork between health workers by establishing good communication and coordination to ensure decision on patient care is made altogether. Besides, it also ensures patient care can be performed optimally and consecutively. The concept of interprofessional collaboration was firstly introduced by the World Health Organization (WHO) in 2010. The WHO announced the need for the development of effective communication strategies, conflict resolution policies, and decisionmaking processes as an organizational culture mechanism. It should follow the interprofessional education and collaborative framework by the WHO to ensure patient safety and service quality (World Health Organization, 2010). Affective communication is one of the priorities in achieving patient safety in patient care (Commission on Hospital Accreditation, 2017).

Besides, service quality and patient safety can be maintained if there are easy access to health care, coordination in services, proper functionality of human resources, and multidisciplinary collaboration which potentially decline complications, length of treatment, conflicts between service providers, therapist malpractices, and even mortality rate (World Health Organization, 2010). A previous study conducted by Setiadi et al. (2017) discovered some constraints in establishing interprofessional collaboration in healthcare centers. The constraints included organizational culture, teamwork management, workplace design and layout, communication, and coordination.

Interprofessional collaborative services require staff to master four basic competencies which are value and ethics, role and responsibility, interprofessional communication, and team/teamwork. The interprofessional collaboration will not work well if one of the basic competencies is neglected (Interprofessional Education Collaborative Expert Panel, 2011).

Interprofessional communication, one of the basic competencies, should be mastered by professional caregivers or Profesional Pemberi Asuhan (PPA). Communication in patient care evolves communication between professional caregivers, as well as patients, and their families. Effective communication essentially can support providing the quality and completeness of patient care in timely and precise manner. The information delivered by caregivers should be understood by receivers. The Regulation of Indonesian Ministry of Health No.11 of 2017 concerning Patient Safety explains that improvement in effective communication is one of the six patient safety targets to establish a service system in healthcare providers (Indonesian Ministry of Health, 2017).

Interprofessional communication can be carried out by (1) opting effective communication strategies; (2) organizing and delivering information to patients, their families, and health workers in understandable written communication; (3) conveying knowledge and opinion confidently, precisely, and respectfully to caregiver team who then decide patient treatment. Moreover, it needs to be performed by (4) listening actively, digging ideas and opinion of other team members, (5) giving time and responding to others' feedback respectfully, (6) communicating in a good manner to avoid conflicts, (7) understanding the attributes of other professions during collaborative work, and (8) communicating with others consistently about patient and community care (Interprofessional Education Collaborative Expert Panel, 2011).

The Meuraxa District General Hospital in Banda Aceh city is a referral type-B district hospital that has been accredited by the Commission on Hospital Accreditation or Komisi Akreditasi Rumah Sakit (KARS) since 2016. The Hospital puts an effort to improve service quality as 
seen in "Guide to Patient Care Service at Meuraxa District General Hospital in Banda Aceh in 2019" concerning Interpofessional Collaboration Practices. However, based on the observation results, the hospital's interprofessional collaboration has not optimally been implemented. The health workers have not applied two-way communication, and there have not been groups who share roles, expertise, and specific professional authorities in altogether decision-making on patient care. Decision-making was dominantly made by doctors in charge or Dokter Penanggung Jawab Pasien (DPJP). Other professional caregivers involved in patient care were more likely to execute and follow the doctors' instructions. They did not collaborate and share any roles. They rarely supervised and recorded patient care in integrated patient progress records or catatan perkembangan pasien terintegrasi (CPPT).

The observation on the integrated patient progress records and interviews with heads of rooms showed the pharmacists had never kept any patient care progress in the progress records since 2019. It indicated that they never took care of patients with their roles and group work. The head pharmacist asserted that the existing pharmacists had not personally taken care of patients, let alone collaboratively.

Interprofessional work collaboration and altogether decision-making will never be created if the professional caregivers prioritize their profession and do not perform two-way interprofessional communication directly or indirectly Therefore, this study aimed to investigate communication between the professional caregivers at Meuraxa District General Hospital in Banda Aceh city according to the concept of interprofessional collaboration.

\section{Method}

This study was qualitative research using a phenomenological approach to identify basic conceptions about individual clinical roles and teamwork among caregivers to achieve the interprofessional collaboration at Meuraxa District General Hospital. Therefore, this study invited the professional caregivers to be the research informants since they were directly engaged in patient care. According to Creswell cited in Sugiyono (2016), a phenomenological approach is used to collect data from participants and thus to understand a phenomenon based on their experience.

This study was conducted at Meuraxa District General Hospital in Banda Aceh city in June-July 2020. The researchers and informants worked at the same hospital. The researchers were managerial staff who did not bound any direct work contract with the informants as caregivers. The informants were doctors in charge, nurses, pharmacists, and dietitians. (1) The doctors should hold a license to practice at the hospital, had signed details of clinical roles or Rincian Kewenangan Klinis (RKK), had worked there for more than 2 years, and were willing to participate. (2) The nurses were clinical nurses at III, IV, and V levels, had a license to practice at the hospital, had signed details of clinical roles, and had worked for more than two years, as well as were willing to be the informants. (3) The pharmacists also held a license to practice at the hospital, had signed details of clinical roles and worked for more than two years, and were willing to be the informants. (4) Dietitians engaged in the research should hold a license to practice at the hospital, had signed details of clinical roles, had worked more than two years, and were willing to be the informants.

Data were then collected in two stages. At the first stage, face-to-face indepth interviews were conducted with each informant in approximately 45 minutes. Each informant was given information about the objective and importance of the research and asked to sign informed consent forms before being invited to the interview. All of the informants agreed to take part in the 
interview. The interview was conducted at the hospital in different locations which were selected beforehand by the researchers and the informants.

The interview was attended by the researchers and each informant. There were no multiple interviews with each informant. The interview was conducted using interview guides which described the broad questions about the interprofessional collaboration practice according to the WHO's framework and core competencies in the Report of an Expert Panel by the Institute of Medicine (IOM). Before the interview, all informants were briefed about the interview guide. The interview was then recorded using a recorder, and all data were collected until they were saturated. Audio transcriptions should match the interview recording and be returned to the informants for crosschecking and feedback.

The researchers themselves did analyze the data based on themes in a top-down manner without using any software. The analysis results at stage I were utilized to guide data collection at stage II. At the stage, Focus Group Discussion (FGD) was conducted to confirm and explore more information about issues arising at stage I. The FGD was done in about 2 hours facilitated by the researchers themselves. It was held in a meeting room with the Medical Commission of Meuraxa General District Hospital where the researchers and informants gathered. The FGD was done once by involving four informants that represented all professions While, informants for FGD were selected from those who had more complete answers during the interview, understood the issues being discussed in the research as well as were willing to participate in the FGD. The FGD was recorded using a recorder, and the results were transcribed and analyzed thematically by the researchers in a top-down manner. The results of in-depth interviews were then triangulated with the analysis results from FGD to yield conclusions.

\section{Result and Discussion}

\section{Informant Characteristics}

Twelve informants were aged about 30-45 years. They were all women, mostly graduated from a bachelor's degree $(58.3 \%)$, and were married $(83.3 \%)$. Regarding their profession, there were three doctors in charge, nurses, pharmacists, and dietitians, respectively $(25 \%)$. Most of the informants had worked for more than 10 years $(66.7 \%)$. Based on the Indonesia Statistics, eight informants had a high income of $>3.5$ million per month (66.7\%) (Table 1).

\section{Communication between Professional Caregivers}

The researchers checked the data multiple times and collected themes matching the interprofessional collaboration frameworks by the WHO and IOM. The final results showed 10 themes in the interprofessional communication.

The FGD was done once by involving four informants that represented all professions. The analysis of in-depth interview results implied that three themes coded 3,5 , and 7 were found to require confirmation and exploration of the information considered contributing to the interprofessional collaboration.

\section{Choosing Effective Communication}

Direct communication was performed when the caregivers visited patients. If the caregivers could not attend the face-to-face visitation, they would communicate via telephone, WhatsApp, and written notes through integrated patient progress records.

"...We directly communicate, but we can also write notes in the integrated patient progress records if impossible to meet..."(02)

"Our communication is normal. If no emergencies happen, we just visit patients as usual. However, if there is an emergency, we may call others. If we do not come across during the visits or emergency, we usually call others." (04) 
Table 1. Informant Characteristics

\begin{tabular}{|c|c|c|}
\hline Category & $\mathbf{N}$ & $\%$ \\
\hline Age (median) & 40 & \\
\hline \multicolumn{3}{|l|}{ Sexes } \\
\hline Man & 0 & 0 \\
\hline Woman & 12 & 100,0 \\
\hline \multicolumn{3}{|l|}{ Education } \\
\hline Diploma & 1 & 8.3 \\
\hline Bachelors & 7 & 58.3 \\
\hline Masters & 4 & 33.3 \\
\hline \multicolumn{3}{|l|}{ Marital Status } \\
\hline Married & 10 & 83.3 \\
\hline Unmarried & 2 & 16.7 \\
\hline \multicolumn{3}{|l|}{ Professions } \\
\hline Doctor in charge & 3 & 25.0 \\
\hline Nurse & 3 & 25.0 \\
\hline Dietitian & 3 & 25.0 \\
\hline Pharmacist & 3 & 25.0 \\
\hline \multicolumn{3}{|l|}{ Work Periode } \\
\hline$<5$ years & 3 & 25.0 \\
\hline $5-10$ years & 1 & 8.3 \\
\hline$>10$ years & 8 & 66.7 \\
\hline \multicolumn{3}{|l|}{ Income (million) } \\
\hline High (>3.5) & 8 & 66.7 \\
\hline Upper Middle (2.5-3.5) & 4 & 33.3 \\
\hline Lower Middle (1.5-2.5) & 0 & 0 \\
\hline Low $(<1.5)$ & 0 & 0 \\
\hline
\end{tabular}

Sources: Primary data

“...We communicate directly via telephone or WhatsApp. Some professions such as nurses need to communicate face to face. Yet, for us, we rarely stay in our workspaces. Dietitian usually meets a doctor when they both visit patients." (06)

The Commission on Hospital Accreditation emphasizes that accredited hospitals should impose caregivers to prioritize patient safety which can be achieved through effective communication (Commission on Health Accreditation, 2017). Caregivers should possess individual skills and collaborative skills to support either direct or indirect effective communication. The caregivers at the hospital should be able to determine means of effective communication according to the current situation. Not to mention, the integrated patient progress records written by the caregivers are supposed to facilitate them to communicate in any circumstances if they carry out the program optimally.

\section{Communicating and organizing information to patients, their families, and health workers in an understandable written notice}

Almost all of the caregivers managed their patient treatment progress by using integrated patient progress records.

\section{"Nurses recorded patient progress in the record. Doctors would record it by themselves. In the same way, the physiotherapist also creates their patient progress records." (01)}

Patient progress recording had been performed well individually by 3 professional caregivers who were the doctor in charge, nurse, and dietitian, respectively. Only pharmacists had not reported any patient progress in the records.

"All of us including doctors, nurses, dietitians, physiotherapists and pharmacists have to report patient progress in the record. However, up to now, the pharmacists have not filled any patient progress yet. This is an exception just for pharmacists. The others filled in the record." (04)

The majority of caregivers explained the pharmacists had not carried out individual care, let alone collaborative care which was not observed in the integrated patient progress records. The pharmacists realized that due to the insufficient number of human resources, the caregivers could not perform clinical and pharmaceutical treatment properly. Despite clinical roles, the pharmacists also were responsible for 
the hospital pharmaceutical management. In their opinion, this task required a lot of time and thus made them difficult to manage their managerial roles and clinical pharmaceutical roles.

"Usually, only doctors, nurses, or dietitians input the patient status in the record, but based on the previous accreditation, the hospital mandates the pharmacists to input the data. They are supposed to be responsible for this role as well. As the pharmacists are so busy, they do not have a chance to meet patients face to face. With many responsibilities, they also need to report prescriptions. Until now, none of the pharmacists visit patients at this hospital. " (05)

Patient care is always dealing with the use of available drugs. For example, the availability, interaction, and side effect of the drugs must be monitored. Of course, only pharmacists can understand most all of these aspects among other professions. The presence of pharmacists in patient care will help the processes of communication, information sharing, and decision-making together. However, if the opposite condition occurs, all of the processes will not work optimally. A previous study conducted at Bantaeng District General Hospital found a strong correlation between the implementation of integrated patient recovery recording and interprofessional collaborative work (Lestari, et al., 2017).

Noting patient status in the records may encourage collaboration to optimize integrated services (Kusumaningrum, et al., 2018). One of the means of communication used at Meuraxa District General Hospital was integrated patient progress records. It was deemed the most effective as it documented all of the notes from all caregivers.

"Usually, all statuses are written on the integrated patient progress records on the same date but in a different hour. Despite that, all of the caregivers' plans were reported

there." (09)

The records could help the caregivers communicate continuously about incoming treatment given by other caregivers with different roles even though they did not meet each other. A literature review concluded communication in the interprofessional collaboration could be improved by noting patient progress in the integrated patient recovery records (Ridar \& Santoso, 2018).

\section{Low literacy of caregivers on patient records and integrated patient progress records}

Although most of the caregivers had accomplished their roles, the majority mentioned they did not read other caregivers' notes. This responsibility has something to do with the personal awareness. Limited time to serve and difficulty in reading others' notes were the reasons why the caregivers did not keep writing the patient progress. Caregivers' notes about consultation and indirect instructions in the records were usually verified by the doctors in charge.

\section{"In reality, it depends on each caregiver. Some caregivers are aware of, and others are not. It is about their unavailable time and difficulty in reading others' notes. However, not all caregivers had the same problems. Some also have verified and checked the records, but others have not. Some only ask about some information." (09)}

The caregivers focused more on their personal task of patient care and thus never collaborated on that. They just summarized all required information for patient treatment. A study on interprofessional collaboration at a hospital found problem-solving from the records was made individually rather than collectively. As a result, patient reporting was centralized based on their expertise or unintegrated between expertises, 
leading to disabled interprofessional collaboration (Susilaningsih, et al., 2017).

Low literacy of the caregivers on the records also possibly leads to patient safety incidence. The Commission on Hospital Accreditation emphasized patient care should prioritize patient safety to the utmost through effective communication, which is writing, reading, and verifying or Tulis Baca Konfirmasi (TBaK) and Situation, Background, Assessment and Recommendation (SBAR) (Commission on Hospital Accreditation, 2017). The Meuraxa General District Hospital has managed the regulation of effective communication for patient care. Caregivers' instructions noted on the records from a direct consultation are supposed to be re-read and verified as well as confirmed for accuracy. If not, patient safety incidence may happen due to less meticulous reading records.

The results from FGD strengthen the finding by saying that the nurses always read patient progress records by the doctors in charge. Contrarily, the dietitians did not read them. The nurses only read important notes, while the dietitians only read notes concerning the patient's nutrition status. This indicated the dietitians rarely read nursing care notes. Besides, the doctors in charge communicated with others more often about patient progress and asked directly about important information once they visited patients along with other caregivers.

"We always read every note in integrated patient progress records from doctor and even checked it multiple times if we feel unsure. We have to read all notes from the doctors even multiple times. While, we just scan the information related to Assessment, Diagnosis, Intervention, Monitoring, and Evaluation (ADIME) informed by the dietitians. The order of information and other items in the ADIME were just scanned." (09)
The records as a means of communication were not optimally used, while ideally, the caregivers had to acknowledge every patient progress from each view of each profession to improve the patient care quality. Different educational backgrounds, knowledge, competency level, affect the caregivers to perform patient care individually. Consequently, they need others' competencies for more optimal patient care. Literature search inferred that good service quality depends on professionals who cooperate with different profession (Rokhmah and Anggorowati, 2017). Research at Sawerigading Palopo District General Hospital also grounded a relationship between education background and teamwork, and a similar finding was also observed at Andi Djemma Masamba District General Hospital (Hardin, 2019).

Low literacy on caregivers' reports occurred since the caregivers were not educated well about interprofessional communication in the professional training. Research on the different perceptions of interprofessional education showed most students majoring at the medical department in Indonesia did not agree with indirect communication between caregivers. They thought that indirect communication would not make them understand about patient progress completely. However, indirect communication including patient status records could support collaborative communication between caregivers (Syahrizal, et al., 2020).

\section{Open education and information to patients and their families}

Almost all of the caregivers ever communicated with patients and their families by educating them and sharing information about the treatment given. They ever gave chances for them to respond to the information. The caregivers used simple language to communicate with patients and their families, thus 
making them more understand the information.

"First, we motivate them and inform them about the benefits and objectives of the treatment. We also explain the consequences if the therapy is not administered. If the patients are not committed, we will then inform the doctors in charge. However, we explain about the objectives and side effects of the therapy first to the patients." (07)

Doctors in charge have the most significant roles in delivering and educating the patients about the information. Patients' trust will improve if the doctors communicate with them directly. A previous study on doctor-patient communication in a primary health care pointed out patient-centered communication could improve patient compliance with medication, achieve medication success, increase patient satisfaction, ease to enforce the diagnosis, and minimize malpractices (Larasati, 2019).

Speaking good words to patients and their families will make them feel respected and prevent conflicts due to inconvenient interactions. Communicating with different patients requires caregivers to master different communication techniques and approaches. Communicating with younger educated patients will be different from that with older patients who have cognitive decline. Culture, language, and patience trait factors are required when caregivers communicate with older patients. They often have troubles when communicating with older patients who have less cognitive abilities. With that said, certain communication techniques applied should be practiced to certain patients, for example by using simple words and speaking slowly (Callinan and Brandt, 2015).

\section{Interpersonal communication between caregivers}

The majority of the caregivers communicated interpersonally instead of interprofessionally. Limited time hampered the communication between the doctors, nurses, and dietitians, especially when they communicated during visits to inpatient rooms. The doctors seemed in hurry due to their packed schedule when serving patients. The dietitians could not stand by all the time in the same room while waiting for the doctors to visit. They were assigned for checking two or three rooms per day; therefore, they sometimes asked the nurses to deliver the information from one profession to another as they did not have a chance to meet face to face and communicate with other professions. For instance, the nurses would inform dietary changes arranged by the dietitians or reported drug interactions and side effects informed by the pharmacists to the doctors in charge. The doctors in charge, pharmacists, and dietitians asserted that the nurses were always available 24 hours in patient rooms and thus present in a call at any time. These results were retrieved from the following interview excerpts.

"Each one first. Nurses will stand by
in the room, so that we can
communicate everytime. But with
doctor, at a later time when you see
a doctor. But if it is an emergency,
we ask for the nurse to contact the
doctor." (08)

As the caregivers rarely met face to face with other professions, they were more likely to reach people working closest to them instead of interacting with all caregivers with the same or different expertise. Communication bridged by the nurses impedes effective interprofessional communication. Irwan Hartana (2016) explained effective communication occurs when all professionals who hold significant roles are in interactive and convenient communication. The effectiveness of communication is determined by the 
validity of information and involvement of professions in idea creation altogether (Hartana, 2016). If nurses do not work with other professions to handle patients, there will be a misperception of patient care.

Communication is conveying of messages between one individual and more to have a mutual understanding. Generally, communication is done using simple words that are understood by two people or more. Not all nurses have good communication to convey messages from other professions. A study conducted at Wava Husada Hospital highlighted contraints in patient care such as doctors' communication styles, limited time of communication, and low nurses' communication competencies (Nazri, et al., 2015).

All of the caregivers involved in the FGD gave stronger evidence that they did not communicate with others in an interprofessional but interpersonal manner. The in-depth interview results further confirmed that the nurses often provided a bridge to deliver messages to other caregivers as the caregivers did not have a chance to meet face to face. This situation occurred because of limited time and perception that communication will be easier with the nurses since they were available in a call at any time.

"We barely meet face to face. However, a nurse will be standby in each room. With that, we usually communicate everything with the nurse. For example, when a patient has lower blood pressure, the nurse will inform the doctor who will then ask him to change the nasogastric tube for administering food. We communicate more frequently with the nurse assigned in the room." (03)

Doctor-nurse communication is more dominant at the hospital. The doctors and nurses admitted that they had the key roles to take care of patients. In doing so, doctor-nurse communication is the most continued and intensive interprofessional collaboration. Utami (2018) mentioned doctors and nurses showed a positive attitude and high interaction and interprofessional collaboration. However, doctors could not deliver all their messages to nurses as they lacked knowledge of the doctors' medication. Wrong information delivered will potentially harm patient safety.

\section{Conveying of opinion and knowledge according to caregivers' expertise}

Most of the caregivers had the freedom to convey their opinion according to their knowledge when collaborating with others.

"We are free to give our opinion to others as long as it is related to our expertise. Like this and that. Others will also speak about their findings." (09)

Some caregivers thought doctors, who had higher responsibility for patient therapy, responded less and just prioritized their tasks.

"...Some doctors agreed with our opinion, but others did not care. Instead, they are the ones who have primary tasks for patient treatment. It is just some though." (07)

Giving of opinion and therapy decision-making were dominated by the doctors, while other professions were reluctant to convey their messages and recommendations according to their expertise. This communication flow will hinder interprofessional collaboration that values the balance of tasks between individuals and teams as recommended by the WHO (World Health Organization, 2010). The same situation also occurred at dr. Sardjito Yogyakarta Central General Hospital where doctors were deemed as leaders who took decisions and gave instructions to other professions including nurses (Fatalina, et al., 2018). 


\section{Active listening and digging for ideas and opinion}

Few caregivers had active communication, for example, sharing information and listening to others' suggestions from the same or different expertise. When they visited patients, they did not exchange any information or receive any opinion from others. Communication between the caregivers was often bridged.

"Overall, doctors want to listen. Well, it depends on whether they accept our opinion or not. Some less care of our opinion, while they hold primary jobs for patient therapy." (07)

"The pharmacist is supposed to be in the room since they need to supervise the food intake which possibly contradicts the drugs prescribed. Therefore, they can exchange information about food restrictions. However, in reality, we never did it." (8)

"I do not know if any dietitian is standby in the room, but everytime I visit the room, there is one there. When I did not visit the patient, I called the nurse to inform me about dietary changes." (12)

Interpersonal communication just transmits messages and exchanges of ideas on patient care from the circle of the same experts. Difficulty in scheduling interprofessional meetings led to the absence of interprofessional visits to inpatient rooms. Normally, regular interprofessional visits may result in advanced patient quality. A study on the effect of mutual visits at a hospital in the United States showed the caregivers could discuss how to identify each patient's problems and progress, as well as patient status for being able to discharged (Reeves, et al., 2017). Another study discovered regular team meeting was an effective strategy to improve coordination and communication between caregivers (Setiadi, et al., 2017).

From the results of FGD, only one informant mentioned that the caregivers ever conducted meetings to dig ideas and opinions from others.

"The dietitians usually give their suggestions by saying 'Doctor, the patient only took the drug at something cc. We have not decided to administer the drug less frequently or more with a smaller volume'. We still listen to their suggestions. The nurses also inform us since they visit patients in 24 hours. We hear patient progress from the nurses or dietitians. While probably the patient then got diarrhea, so they need to rub oil or use other ways. The nurses or dietitians will inform us as well. The dietitian said, 'Doctor, the calorie intake can be sourced from the food, not low-fat food.' So, we still communicate with each other." (12)

The results of FGD reinforce the results of the in-depth interviews. Active listening to ideas and recommendations based on the expertise was only confirmed by very few caregivers. Meanwhile, interprofessional collaboration integrates all expertises to formulate service models (Canadian Interprofessional Health Collaborative, 2010)

\section{Giving of time and responding feedback respectfully between caregivers}

Very few caregivers confirmed that the caregivers gave feedback respectfully to the progress of patients under others' supervision.

“...But, hmm we need to admit that we do not cooperate with other professions. For us as pharmacists, we could collaborate with other 
pharmacists assigned for patient care well. However, there is no formal discussion at all. If an incident occurs, we take action individually with caregivers who have the same expertise..." (03)

Lack of communication between caregivers impedes cooperation and the need for information exchanges to optimize the hospital services. Interprofessional collaboration is a state where a variety of health workers work together with patients, their families, other professions, and the community to provide good quality service (World Health Organization, 2010).

\section{Communicating in a good manner to avoid conflicts between caregivers}

All of the informants communicated with good words to avoid conflicts. The conflict management either for individual conflicts or complicated conflicts between groups had been performed well. Individual conflicts were resolved through direct confirmation to parties in conflict, and complicated conflicts were solved with the help of hospital management.

"...We speak to the person decisively without being opinionated in addition to that our knowledge is lower than the seniors'. Although they do not accept our arguments, we feel good because we can solve the conflicts. It is the most important..." (03)

Susilaningsih (2016) cited in Rokhmah (2017) argued hospital services involve multidisciplinary services which potentially overlap, cause interprofessional conflicts, and tardiness in medical check and treatment. The conflict management among the caregivers at the hospital ran well. Miscommunication arising often could still be resolved individually although some miscommunication still required the hospital management's help. All conflicts must be resolved through reconciliation, thereby avoiding any resentment. Resentment is the state where someone is reluctant to meet in caring of patients together. The literature search found good services depend on the types of professions who work in a team (Rokhmah and Anggorowati, 2017). The caregivers would feel safe and comfortable in caring for patients together if they communicated with each other respectfully.

\section{Understanding the attributes of other professions in the collaborative work}

The caregivers understood that in certain circumstances, they should consult about a patient condition with other professions. The result is according to the following interview excerpt.

\section{"In handling patients, we need other professions, either nurses, dietitians, or pharmacists. All of them need to work together to treat a patient." (10)}

Caregivers cannot give treatment to patients and convey information that is not relevant to their competencies. Every profession has its attributes. The collaboration will not be optimal if one of the professions does not contribute to taking care of patients. Collaboration is interprofessional communication and decision-making in which healthcare workers can share their knowledge and capabilities for patient treatment (Canadian Interprofessional Health Collaborative, 2012).

\section{Conclusion}

Communication between caregivers in establishing interprofessional collaboration at Meuraxa District General Hospital was not optimal yet. The caregivers did not have competencies of interprofessional collaboration as expected. As a result, communication just occurred in the interpersonal but interprofessional manner. Integrated Patient progress records were not functioned well by the caregivers who 
tended to focus on their task of patient care. Moreover, caregivers' literacy on the patient records was lacking. Time limitation for service and the inadequate number of human resources are assumed to hamper interprofessional communication.

It is suggested that the hospital evaluates the needs of caregivers by considering the workload analysis and balance in collaborative service provision. The hospital management could recruit more human resources, especially pharmacists to optimally perform clinical pharmaceutical treatment for inpatients.

Regulations on communication through interprofessional collaboration need to be formulated comprehensively and should not be limited to the application of writing, reading, and verifying techniques as well as Situation, Background, Assessment, Recommendation (SBAR) techniques. The hospital has to develop and adjust the regulations for collaborative work according to the guidelines of interprofessional collaboration by the WHO, Canadian Interprofessional Health Collaborative, Interprofessional Education Collaborative Expert Panel, and other organizations. The regulations must be promoted continuously to make caregivers understand interprofessional collaboration.

Regular training on effective communication is necessary to conduct. Besides, the hospital management needs to form supervision and evaluation mechanisms for direct communication i.e., patient visitation and indirect communication i.e., integrated patient progress records. All of these efforts are made to enable communication among all professions to work on providing optimal patient care.

\section{Abbreviations}

RSUD: Rumah Sakit Umum Daerah (District General Hospital); FGD: Focus Group Discussion; PPA: Profesional Pemberi Asuhan (Professional Caregiver); DPJP: Dokter Penanggung Jawab Pasien (Doctor in charge); CPPT: Catatan Perkembangan Pasien Terintegrasi (Integrated Patient Progress Record);
SDM: Sumber Daya Manusia (Human resource); WHO: World Health Organization; KARS: Komisi Akreditasi Rumah Sakit ( Commission on Health Accreditation); RKK: Rincian Kewenangan Klinis (Clinical roles); ADIME: Assesment, Diagnosis, Intervention, Monitoring and Evaluation; TBaK: Tulis, Baca, Konfirmasi (Writing, Reading and Verifying); SBAR: Situation, Background, Assesment and Recommendation.

\section{Declarations}

Ethics approval and consent to parcitipate: this study has been approved by the Commission on Research Ethics, Faculty of Medicine, Syiah Kuala University, and dr. Zainoel Abidin District General Hospital with No. 083/EA/FKRSUDZA/2020. Conflict of interest: there is no conflict of interest in the research. Availability of data and material: not applicable. Funding: none. Author's contributions: conceived, drafted and revised the manuscript.

Acknowledgements: none.

\section{References}

Agusrianti, P. (2015). Analisis FaktorFaktor yang Berhubungan dengan Efektivitas Komunikasi Perawat dan Pasien di Ruang Rawat Inap Rumah Sakit Harapan Mulia Kabupaten Bekasi Tahun 2015. Jurnal Administrasi Rumah Sakit, 2(1), 7283.

Callinan, S., and Brandt, N. (2015). Tracling Communication Barriers Between Long-Term Care Facility and Emergency Departement Transfers to Improve Medication Safety in Older Adult. Journal of Gerontological Nursing, 41(7), 8-13.

Canadian Interprofessional Health Collaborative. (2010). A National Interprofessional Competency Framework. Vancouver, BC, Canada: Canadian Interprofessional Health Collaborative.

Canadian Interprofessional Health Collaborative. (2012). An Inventory of Quantitative Tools Measuring Interprofessional Education and 
Collaborative Practice Outcomes.

Canada: Canadian Interprofessional Collaboration Health Collaborative.

Fatalina, F., Sunartini, Widyandana, and Sedyowinarso, M. (2018). Persepsi dan Penerimaan Interprofessional Collaboration Practice Bidang Maternitas pada Tenaga Kesehatan. Jurnal Pendidikan Kedokteran Indonesia, 4(1), 28-36.

Hardin. (2019). Faktor-Faktor yang Berhubungan dengan Praktik Kolaborasi Perawat- Dokter di RSUD Sawerigading Palopo dan RSUD Andi Djemma Masamba. Jurnal Fenomena Kesehatan, 2(1), 155164.

Hartana, I. (2016). Komunikasi yang Efektif. Retrieved 2020, from I-Care Institute: https://ot.id/tipsprofesional/komunikasi-yang-efektif

Interprofessional Education Collaborative Expert Panel. (2011). Core competencies for interprofessional collaborative practice : Report of an expert panel. Washington, D.C: Interprofessional Education Collaborative.

Kementerian Kesehatan RI. (2017). Peraturan Menteri Kesehatan Republik Indonesia Nomor 11 Tahun 2017. Retrieved September 25, 2020, from Biro Hukum dan Organisasi Kementerian Kesehatan Republik Indonesia: http://hukor.kemkes.go.id/hukor/sear ch

Komisi Akreditasi Rumah Sakit. (2017). Standar Nasional Akreditasi Rumah Sakit (I ed.). (P. H. Garna, Ed.) Jakarta Selatan, Indonesia: Komisi Akreditasi Rumah Sakit (KARS).

Kusumaningrum, P., Dharmana, E., and Sulisno, M. (2018). The Implementation of Integrated Patient Progress Notes in Interprofessional Collaborative Practice. Jurnal Ners dan Kebidanan Indonesia, 6(1), 3241.

Larasati, T. A. (2019). Komunikasi DokterPasien Berfokus Pasien pada Pelayanan Kesehatan Primer. Jurnal Kedokteran Universitas Lampung, 3(1), 160-166.
Lestari, Y., Ariyanti, S., and Pasinringi, S. (2017). Hubungan Interprofesional Kolaborasi dengan Pelaksanaan Catatan Perkembangan Pasien Terintegrasi di RSUD. Prof. DR. H.M. Anwar Makkatutu Kabupaten Bantaeng. JST Kesehatan, 7(1), 8590.

Nazri, F., Juhariah, S., and Arif, M. (2015). Implementasi Komunikasi Efektif Perawat-Dokter dengan Telepon di Ruang ICU Rumah Sakit Wava Husada. Jurnal Kedokteran Brawijaya, 28(2), 174-180.

Norouzinia, R., Aghabarari, M., Shiri, M., Karimi, and Samami, E. (2016). Communication Barriers Perceived by Nurses and Patients. Global Journal of Health Science, 8(6), 6574.

Reeves, S., Pelone, F., Harrison, R., Goldman, J., and Zwarenstein, M. (2017). Interventions to Improve Professional Practice and Healthcare Outcomes (Review). Cochrane Database Systematic Reviews(6), 11-12.

Ridar, I., and Santoso, A. (2018). Peningkatan Komunikasi dalam Pelaksanaan Interprofessional Collaboration melalui Catatan Perkembangan Pasien Terintegrasi. Prosiding Seminar Nasional Unimus, 1, 144-149.

Rokhmah, N. A., and Anggorowati. (2017). Komunikasi Efektif dalam Praktek Kolaborasi Interprofesi Sebagai Upaya Meningkatkan Kualitas Pelayanan. Journal of Health Studies, 1(1), 65-71.

RSUD Meuraxa. (2019). Panduan Pelaksanaan Komunikasi Efektif.

Setiadi, A., Wibowo, Y., Herawati, F., Irawati, S., Setiawan, E., Presley, B., et al. (2017). Factors Contributing to Interprofessional Collaboration in Indonesian Health Centres: A Focus Group Study. Journal of Interprofessional Education and Practice, 8, 69-74.

Susilaningsih, F., Mediani, H., Kurniawan, T., Widiawati, M., Maryani, L., and Meharawati, I. (2017). Sosialisasi Model Praktik Kolaborasi Interprofesional Pelayanan 
Kesehatan di Rumah Sakit. Jurnal Aplikasi Ipteks untuk Masyarakat, 6(1), 10-13.

Syahrizal, D., Renaldi, T., Dianti, S., Jannah, N., Rachmah, R., Firdausa, S., et al. (2020). The Differences in Perceptions of Interprofessional Education Among Health Profession Students: The Indonesian Experience. Journal of Multidisciplinary Healthcare, 13, 403410.

Utami, L. C. (2018). Gambaran Sikap Kolaborasi Interprofesi PerawatDokter di Instalasi Rawat InapRSD dr. Soebandi Jember. Universitas Jember, Program Studi Sarjana Keperawatan Fakultas Keperawatan. Jember: Digital Repository Universitas Jember.

World Health Organization. (2010). Framework for Action on Interproffessional Education and Collaborative Practice. Geneva 27, Switzerland: World Health Organization Press/Health Professions Networks/ Nursing and Midwifery/ Human Resources for Health. 